\title{
Halogranum gelatinilyticum sp. nov. and Halogranum amylolyticum sp. nov., isolated from a marine solar saltern, and emended description of the genus Halogranum
}

Correspondence

Heng-Lin Cui

cuihenglin@sohu.com

\author{
Heng-Lin Cui, ${ }^{1}$ Xin Yang, ${ }^{1}$ Xia Gao ${ }^{1}$ and Xue-Wei $X^{2}$
}

\author{
${ }^{1}$ School of Food \& Biological Engineering, Jiangsu University, Zhenjiang 212013, PR China \\ ${ }^{2}$ Second Institute of Oceanography, State Oceanic Administration, Hangzhou 310012, PR China
}

\begin{abstract}
Two extremely halophilic archaeal strains, designated TNN44 ${ }^{\top}$ and $\mathrm{TNN}^{\mathrm{N}} \mathrm{8}^{\mathrm{T}}$, were isolated from Tainan marine solar saltern near Lianyungang city, Jiangsu province, China. Cells of the two strains were pleomorphic and Gram-stain-negative; colonies were red-pigmented. Strains TNN44 ${ }^{\top}$ and TNN58 $8^{\top}$ were able to grow at $20-50{ }^{\circ} \mathrm{C}$ (optimum $37^{\circ} \mathrm{C}$ for both), in the presence of 1.4-5.1 M NaCl (optimum 3.4-3.9 M NaCl) and at pH 5.5-9.0 (optimum pH 6.5-7.0); neither strain required $\mathrm{Mg}^{2+}$ for growth. Cells lysed in distilled water. On the basis of 16S rRNA gene sequence analysis, strains TNN44 ${ }^{\top}$ and TNN58 ${ }^{\top}$ were related closely to Halogranum rubrum $\mathrm{RO} 2-11^{\top}$ (96.2 and $97.2 \%$ similarity, respectively). The polar lipids of the two strains were phosphatidylglycerol, phosphatidylglycerol phosphate methyl ester, phosphatidylglycerol sulfate (trace), and one major glycolipid and one minor glycolipid chromatographically identical to sulfated mannosyl glucosyl diether and mannosyl glucosyl diether, respectively; other trace unidentified lipids were also detected. The DNA G $+C$ content of strains TNN44 ${ }^{\top}$ and TNN58 ${ }^{\top}$ was 64.0 and $62.0 \mathrm{~mol} \%$, respectively. The level of DNA-DNA relatedness between strains TNN44 $^{\top}$ and TNN58 ${ }^{\top}$ was $37.2 \%$, and these two strains showed a low level of DNA-DNA relatedness with Halogranum rubrum $\mathrm{RO} 2-11^{\top}$ ( 40.6 and $44.4 \%$, respectively). Two novel species of the genus Halogranum are proposed to accommodate these two strains, Halogranum gelatinilyticum sp. nov. (type strain TNN44 ${ }^{\top}=$ CGMCC $1.10119^{\top}=\mathrm{JCM} 16426^{\top}$ ) and Halogranum amylolyticum sp. nov. (type strain TNN58 ${ }^{\top}=$ CGMCC $1.10121^{\top}=J C M 16428^{\top}$ ).
\end{abstract}

Marine solar salterns, man-made shallow ponds for the production of halite from seawater, serve as comfortable habitats for diverse halophilic micro-organisms. Among these halophilic micro-organisms, halophilic archaea are probably the dominant microbes at saltern crystallizer ponds (Oren, 2002). To understand better the biogeographical distribution and diversity of halophilic archaeal communities within different marine solar salterns along the coastline of eastern China (Cui et al., 2010), brine and sediment samples were collected from Tainan marine solar saltern ( $\left.34^{\circ} 35^{\prime} 38^{\prime \prime} \mathrm{N} 119^{\circ} 28^{\prime} 56^{\prime \prime} \mathrm{E}\right)$ near Lianyungang city, Jiangsu province, and their halophilic archaeal

Abbreviations: PG, phosphatidylglycerol; PGP-Me, phosphatidylglycerol phosphate methyl ester; PGS, phosphatidylglycerol sulfate; (S)-DGD, (sulfated) mannosyl glucosyl diether.

The GenBank/EMBL/DDBJ accession numbers for the 16S rRNA gene sequences of strains $\mathrm{TNN}^{\mathrm{T}}{ }^{\top}$ and $\mathrm{TNN}^{\mathrm{T}} \mathrm{S}^{\mathrm{T}}$ are GQ282624 and GQ282623, respectively.

Three supplementary figures are available with the online version of this paper. diversity was examined based on analysis of a library of PCR-amplified 16S rRNA genes and by cultivation. Of 65 isolates examined, one strain showed $99.9 \% 16 \mathrm{~S}$ rRNA gene sequence similarity to the type strain of Salinibacter ruber (Antón et al., 2002); the other 64 strains belonged to the family Halobacteriaceae. Two of these halophilic archaeal strains, designated $\mathrm{TNN} 44^{\mathrm{T}}$ and $\mathrm{TNN} 58^{\mathrm{T}}$, were closely related to Halogranum rubrum, the single member of the genus Halogranum. Based on the data presented in this study, we suggest that strains TNN $44^{\mathrm{T}}$ and TNN $58^{\mathrm{T}}$ represent two novel species of the genus Halogranum.

Neutral oligotrophic haloarchaeal medium (NOM) was used for isolation, and comprised (per litre): $0.05 \mathrm{~g}$ yeast extract, $0.25 \mathrm{~g}$ fish peptone, $1.0 \mathrm{~g}$ sodium pyruvate, $5.4 \mathrm{~g}$ $\mathrm{KCl}, 0.3 \mathrm{~g} \mathrm{~K}_{2} \mathrm{HPO}_{4}, 0.25 \mathrm{~g} \mathrm{CaCl}_{2}, 0.25 \mathrm{~g} \mathrm{NH}_{4} \mathrm{Cl}, 26.8 \mathrm{~g}$ $\mathrm{MgSO}_{4} \cdot 7 \mathrm{H}_{2} \mathrm{O}, 23.0 \mathrm{~g} \mathrm{MgCl}_{2} .6 \mathrm{H}_{2} \mathrm{O}$ and $184.0 \mathrm{~g} \mathrm{NaCl}(\mathrm{pH}$ adjusted to 7.0-7.2 with $1 \mathrm{M} \mathrm{NaOH}$ solution) (Cui et al., 2010). The medium was solidified with $2.0 \%$ agar. The strains were routinely grown aerobically at $37^{\circ} \mathrm{C}$ in NOM3 medium (NOM series medium) with the following modifications (per litre): $1.0 \mathrm{~g}$ yeast extract, $0.25 \mathrm{~g}$ fish 
peptone, $0.25 \mathrm{~g}$ sodium formate, $0.25 \mathrm{~g}$ sodium acetate, $0.25 \mathrm{~g}$ sodium lactate and $0.25 \mathrm{~g}$ sodium pyruvate.

Phenotypic tests were performed according to the proposed minimal standards for description of new taxa in the order Halobacteriales (Oren et al., 1997). Halogranum rubrum RO2-11 ${ }^{\mathrm{T}}$, Haloferax elongans JCM $14791^{\mathrm{T}}$ and Halobacterium salinarum CGMCC 1.2367 were selected as reference strains in subsequent tests. Cell morphology and motility in exponentially growing liquid cultures were examined by using a Nikon microscope equipped with phase-contrast optics (model E400). Minimal salt concentration to prevent cell lysis was tested by suspending washed cells in serial sterile saline solutions containing $\mathrm{NaCl}$ at $0-15 \%(\mathrm{w} / \mathrm{v})$, and the stability of the cells was detected by light microscopy.

Gram staining was performed by following the method outlined by Dussault (1955). Most miscellaneous biochemical tests and nutritional tests were performed as described and proposed by Oren et al. (1997). Briefly, growth and gas formation with nitrate as electron acceptor were tested in $9 \mathrm{ml}$ stoppered tubes, completely filled with liquid NOM medium to which $\mathrm{NaNO}_{3}\left(5 \mathrm{~g} \mathrm{l}^{-1}\right)$ had been added, and containing an inverted Durham tube. The formation of gas from nitrate was detected based on the presence of gas bubbles in Durham tubes, and the formation of nitrite was monitored colorimetrically. Anaerobic growth in the presence of L-arginine and DMSO $\left(5 \mathrm{~g} \mathrm{l}^{-1}\right)$ was tested in completely filled $9 \mathrm{ml}$ stoppered tubes. Starch hydrolysis was determined on NOM agar plates supplemented with soluble starch $\left(2 \mathrm{~g} \mathrm{l}^{-1}\right)$ and was detected by flooding the plates with Lugol's iodine solution. Gelatin hydrolysis was performed by growing colonies on NOM agar plates amended with $1 \%(\mathrm{w} / \mathrm{v})$ gelatin and flooding the plates with Frazier's reagent (McDade \& Weaver, 1959) after growth was established. Esterase activity was detected as outlined by Gutiérrez \& González (1972). Tests for catalase and oxidase activities were performed as described by Gonzalez et al. (1978). Production of $\mathrm{H}_{2} \mathrm{~S}$ was tested by growing the isolates and reference strains in a tube with the NOM liquid medium supplemented with $0.5 \%$ $(\mathrm{w} / \mathrm{v})$ sodium thiosulfate; a filter-paper strip impregnated with lead acetate was used for $\mathrm{H}_{2} \mathrm{~S}$ detection (Cui et al., 2007). To test for growth on single carbon sources, fish peptone and sodium pyruvate were omitted from the NOM medium and the compound to be tested was added at a concentration of $5 \mathrm{~g} \mathrm{l}^{-1}$. Antibiotic susceptibilities were determined according to the method described by Gutiérrez et al. (2008) on NOM agar plates with discs containing the following antibiotics ( $\mu \mathrm{g}$ per disc, unless otherwise indicated): ampicillin (10), anisomycin (20), aphidicolin (20), bacitracin (0.04 IU per disc), chloramphenicol (30), ciprofloxacin (5), erythromycin (15), gentamicin (10), kanamycin (30), nalidixic acid (30), neomycin (30), norfloxacin (10), novobiocin (30), penicillin G (10 IU per disc), rifampicin (5), streptomycin (10), tetracycline (30) and vancomycin (30).
Polar lipids were extracted by using a chloroform/methanol system and were analysed via one- and two-dimensional TLC, as described by Kates (1986). Merck silica gel $60 \mathrm{~F}_{254}$ aluminium-backed thin-layer plates were used in TLC analysis. The plate for detecting phospholipids was subjected to two-dimensional development, with the first solvent of chloroform/methanol/water $(65: 25: 4$, by vol.) followed by the second solvent of chloroform/methanol/ acetic acid/water ( $80: 12: 15: 4$, by vol.), then sprayed with the phosphate stain reagent (Vaskovsky \& Kostetsky, 1968). To determine the phospholipid and glycolipid composition of each strain extract, the two-dimensional development plate was sprayed with sulfuric acid/ethanol $(1: 2, \mathrm{v} / \mathrm{v})$ followed by heating at $150{ }^{\circ} \mathrm{C}$ for $3 \mathrm{~min}$ to detect lipids. To compare the polar lipid composition of the two novel strains with the reference strains, the plate was subjected to single development in the above-mentioned second dimensional development solvent, and then sprayed with the same sulfuric acid/ethanol reagent followed by heating at $150{ }^{\circ} \mathrm{C}$ for 3 min to detect lipids.

Genomic DNA from halophilic archaeal strains was prepared as described by $\mathrm{Ng}$ et al. (1995). The $16 \mathrm{~S}$ rRNA gene was amplified via PCR by using primers $0018 \mathrm{~F}$ and 1518R (Cui et al., 2009). PCR was performed in a thermal cycler (MJ Research PTC-150) for 30 cycles (5 min denaturing at $95{ }^{\circ} \mathrm{C}$ in the first cycle; 1 min denaturing at $95{ }^{\circ} \mathrm{C}, 1 \mathrm{~min}$ annealing at $60{ }^{\circ} \mathrm{C}$ and 1.5 min elongation at $72{ }^{\circ} \mathrm{C}$; final extension step at $72{ }^{\circ} \mathrm{C}$ for $\left.10 \mathrm{~min}\right)$. The PCR products were examined on a $1.0 \%(\mathrm{w} / \mathrm{v})$ agarose gel and then cloned into the pEASY-T vector (TransGen Biotech) and transformed into cells of Escherichia coli Mach1. Sixteen transformants were randomly picked and sequenced at the Sino-GenoMax Company Limited (Beijing, China), to determine whether the two novel strains possessed multiple distinct $16 \mathrm{~S}$ rRNA gene sequences. Multiple sequence alignments were performed by using the CLUSTAL $\mathrm{W}$ program integrated in MEGA 4 software (Tamura et al., 2007). Phylogenetic trees were reconstructed with the neighbour-joining (Saitou \& Nei, 1987) and maximum-parsimony (Fitch, 1971) algorithms in MEGA 4 software. The percentages of trees in which the associated taxa clustered together in the bootstrap test were determined based on 1000 replicates. Levels of $16 \mathrm{~S}$ rRNA gene sequence similarity were calculated by comparison with sequences of related halophilic archaea from the online EzTaxon server (Chun et al., 2007). The DNA G + C content was determined by the HPLC method (Mesbah et al., 1989). DNA-DNA hybridization analyses were performed according to the thermal denaturation and renaturation method of De Ley et al. (1970) as modified by Huß et al. (1983).

Cells of strains $\mathrm{TNN} 44^{\mathrm{T}}$ and $\mathrm{TNN} 58^{\mathrm{T}}$ were pleomorphic short rods, irregular cocci and ovals when grown in NOM liquid medium (see Supplementary Fig. S1 available in IJSEM Online). Cells of strain TNN44 ${ }^{\mathrm{T}}$ were motile, while those of strain $\mathrm{TNN}^{2} 8^{\mathrm{T}}$ were not. Cells stained Gramnegative and colonies were red-pigmented. Strains $\mathrm{TNN}_{4} 4^{\mathrm{T}}$ 
and $\mathrm{TNN} 58^{\mathrm{T}}$ were able to grow at $20-50{ }^{\circ} \mathrm{C}$ (optimum $37{ }^{\circ} \mathrm{C}$ for both), in the presence of $1.4-5.1 \mathrm{M} \mathrm{NaCl}$ (optimum 3.4-3.9 M NaCl) and at $\mathrm{pH}$ 5.5-9.0 (optimum pH 6.5-7.0); neither strain required $\mathrm{Mg}^{2+}$ for growth. Cells lysed in distilled water and the minimal $\mathrm{NaCl}$ concentrations to prevent cell lysis were $10 \%(\mathrm{w} / \mathrm{v})$ for strain $\mathrm{TNN}_{4} 4^{\mathrm{T}}$ and $8 \%(\mathrm{w} / \mathrm{v})$ for strain $\mathrm{TNN} 58^{\mathrm{T}}$. The two strains produced indole from tryptophan, but did not produce $\mathrm{H}_{2} \mathrm{~S}$ from sodium thiosulfate. Strain TNN $44^{\mathrm{T}}$ hydrolysed gelatin and starch (the latter only weakly); by contrast, strain TNN $58^{\mathrm{T}}$ did not hydrolyse gelatin but hydrolysed starch strongly. The two strains did not hydrolyse Tween 80 or casein. They were able to grow in defined and complex media; D-glucose, D-mannose, D-galactose, sucrose, lactose, glycerol, acetate, pyruvate and DL-lactate as single carbon sources yielded the best growth. Acid was produced during growth on some carbohydrates. Detailed results of phenotypic tests and nutritional characteristics of the two strains are given in the species descriptions below.

The polar lipids of the two strains were phosphatidylglycerol (PG), phosphatidylglycerol phosphate methyl ester (PGP-Me), trace phosphatidylglycerol sulfate (PGS), one major glycolipid (GL1) and a minor glycolipid (GL2) chromatographically identical to sulfated mannosyl glucosyl diether (S-DGD-1) and mannosyl glucosyl diether (DGD-1), respectively; other trace unidentified glycolipids (GL3, GL4, GL5 and GL6) were also detected (Supplementary Fig. S2). The polar lipid profiles of the two strains were largely chromatographically identical to those of Halogranum rubrum RO2-11 ${ }^{\mathrm{T}}$ (Supplementary Fig. S2). The polar lipid composition thus supports the classification of strains $\mathrm{TNN}^{\mathrm{T}}{ }^{\mathrm{T}}$ and $\mathrm{TNN} 58^{\mathrm{T}}$ in the genus Halogranum.

Sixteen complete 16S rRNA gene sequences of strains TNN44 ${ }^{\mathrm{T}}$ and $\mathrm{TNN}^{2} 8^{\mathrm{T}}$ were obtained. Comparisons indicated that the two strains each have one type of $16 \mathrm{~S}$ rRNA gene sequence, and that they share $96.4 \%$ similarity. The two strains were related closely to Halogranum rubrum RO2-11 ${ }^{\mathrm{T}}$ (96.2 and $97.2 \%$ 16S rRNA gene sequence similarity, respectively). Phylogenetic analysis using the neighbour-joining algorithm revealed that strains TNN $44^{\mathrm{T}}$ and TNN58 ${ }^{\mathrm{T}}$ clustered tightly with Halogranum rubrum RO2-11 ${ }^{\mathrm{T}}$ (Fig. 1). This phylogenetic position was also confirmed in the tree generated with the maximum-parsimony algorithm (Supplementary Fig. S3). Phylogenetic analysis based on 16S rRNA gene sequences thus also supported the placement of strains $\mathrm{TNN} 44^{\mathrm{T}}$ and $\mathrm{TNN} 44^{\mathrm{T}}$ in the genus Halogranum.

The DNA G + C content of strains $\mathrm{TNN} 44^{\mathrm{T}}$ and $\mathrm{TNN} 58^{\mathrm{T}}$ were 64.0 and $62.0 \mathrm{~mol} \%$, respectively. These values are higher than those reported for Halogranum rubrum (55.7$57.6 \mathrm{~mol} \%$ ) (Cui et al., 2010). The level of DNA-DNA relatedness between strains $\mathrm{TNN}^{\mathrm{T}} 4^{\mathrm{T}}$ and $\mathrm{TNN} 58^{\mathrm{T}}$ was $37.2 \%$, showing that the two strains should be classified as representing two different species, as the generally accepted threshold value to separate two species is $70 \%$ (Stackebrandt \& Goebel, 1994). Strains TNN44 ${ }^{\mathrm{T}}$ and $\mathrm{TNN} 58^{\mathrm{T}}$ showed low levels of DNA-DNA relatedness to Halogranum rubrum $\mathrm{RO} 2-11^{\mathrm{T}}$ (40.6 and $44.4 \%$, respectively), which indicated that the two strains are related more closely to Halogranum rubrum $\mathrm{RO} 2-11^{\mathrm{T}}$ than to each other at the DNA-DNA hybridization level and represent two distinct species of the genus Halogranum.

This polyphasic taxonomic study provides evidence that strains TNN44 ${ }^{\mathrm{T}}$ and $\mathrm{TNN} 58^{\mathrm{T}}$ represent two novel species of the genus Halogranum, for which the names Halogranum gelatinilyticum sp. nov. (type strain $\mathrm{TNN} 44^{\mathrm{T}}=$ CGMCC $1.10119^{\mathrm{T}}=\mathrm{JCM} 16426^{\mathrm{T}}$ ) and Halogranum amylolyticum sp. nov. (type strain TNN58 ${ }^{\mathrm{T}}=$ CGMCC $1.10121^{\mathrm{T}}=\mathrm{JCM}$ $16428^{\mathrm{T}}$ ) are proposed. Characteristics that distinguish strains TNN44 ${ }^{\mathrm{T}}$ and $\mathrm{TNN} 58^{\mathrm{T}}$ from Halogranum rubrum $\mathrm{RO} 2-11^{\mathrm{T}}$ are shown in Table 1.

\section{Emended description of the genus Halogranum Cui et al. 2010}

Cells are pleomorphic under optimal growth conditions and stain Gram-negative. Aerobic heterotrophs. Cells lyse in distilled water. Oxidase- and catalase-positive. Extremely halophilic, with growth occurring in media containing 1.4$5.1 \mathrm{M} \mathrm{NaCl}$; most strains grow best at $3.4-3.9 \mathrm{M} \mathrm{NaCl}$. The optimum magnesium concentration varies between 0.05 and $0.3 \mathrm{M}$. Growth is observed at $20-50{ }^{\circ} \mathrm{C}$ and at $\mathrm{pH}$ 5.5-9.0. Sugars are metabolized, in some cases with the formation of acids. The polar lipids are PG, PGP-Me, trace PGS, and one major glycolipid and one minor glycolipid chromatographically identical to S-DGD-1 and DGD-1, respectively; other trace unidentified glycolipids may be present. The genomic DNA G $+\mathrm{C}$ content is between 55.7

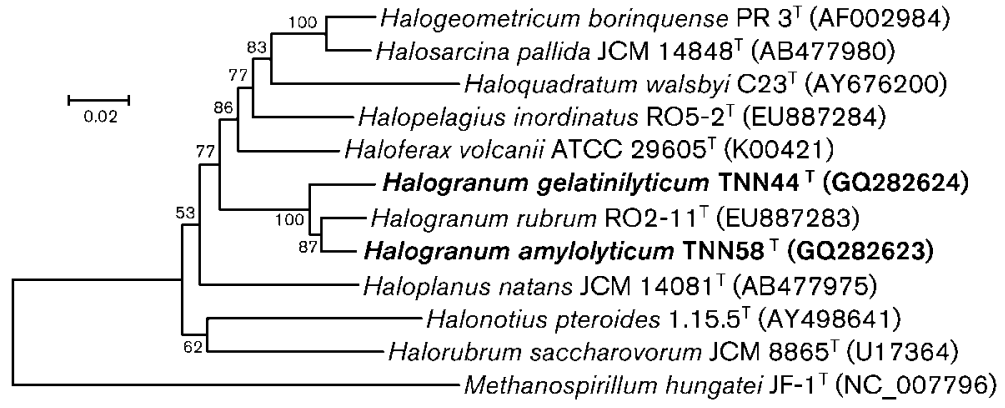

Fig. 1. Neighbour-joining phylogenetic tree based on 16S rRNA gene sequences showing the relationship between strains TNN44 ${ }^{\top}$ and TNN58 ${ }^{\top}$ and other close relatives within the family Halobacteriaceae. Bootstrap values (percentages) are based on 1000 replicates and are shown for branches with more than $50 \%$ support. Bar, 0.02 substitutions per nucleotide position. 
Table 1. Characteristics that distinguish strains $T N N 44^{\top}$ and $\mathrm{TNN}^{\mathrm{T}} \mathrm{T}^{\mathrm{T}}$ from Halogranum rubrum $\mathrm{RO} 2-11^{\mathrm{T}}$

Strains: $1, \mathrm{TNN}_{4} 4^{\mathrm{T}} ; 2, \mathrm{TNN}^{\mathrm{T}} 8^{\mathrm{T}} ; 3$, Halogranum rubrum $\mathrm{RO} 2-11^{\mathrm{T}}$ (data from Cui et al., 2010). +, Positive; -, negative; w, weakly positive.

\begin{tabular}{|c|c|c|c|}
\hline Characteristic & 1 & 2 & 3 \\
\hline Motility & + & - & + \\
\hline $\begin{array}{l}\text { Minimal salt concentration to prevent } \\
\text { cell lysis }(\%)\end{array}$ & 10 & 8 & 12 \\
\hline Optimum $\mathrm{NaCl}(\mathrm{M})$ & $3.4-3.9$ & 3.4 & 3.9 \\
\hline $\mathrm{Mg}^{2+}$ required & - & - & + \\
\hline Optimum pH & 7.0 & 6.5 & 7.5 \\
\hline Reduction of nitrate to nitrite & - & + & + \\
\hline \multicolumn{4}{|l|}{ Utilization of: } \\
\hline Maltose & - & + & + \\
\hline Lactose & $\mathrm{W}$ & + & + \\
\hline D-Mannitol & - & + & - \\
\hline D-Sorbitol & $\mathrm{w}$ & + & + \\
\hline Succinate & - & + & + \\
\hline L-Malate & - & + & + \\
\hline Fumarate & - & + & + \\
\hline Glycine & - & + & - \\
\hline L-Alanine & + & + & $\mathrm{w}$ \\
\hline L-Ornithine & + & + & $\mathrm{w}$ \\
\hline Indole formation & + & + & - \\
\hline Starch hydrolysis & $\mathrm{W}$ & + & w \\
\hline Gelatin hydrolysis & + & - & + \\
\hline Tween 80 hydrolysis & - & - & + \\
\hline $\mathrm{H}_{2} \mathrm{~S}$ formation & - & - & + \\
\hline DNA G $+C$ content $(\mathrm{mol} \%)$ & 64.0 & 62.0 & 55.7 \\
\hline
\end{tabular}

and $64.0 \mathrm{~mol} \%$. Isolated from marine solar salterns. The type species is Halogranum rubrum.

\section{Description of Halogranum gelatinilyticum sp. nov.}

Halogranum gelatinilyticum [ge.la.ti.ni.ly'ti.cum. N.L. neut. n. gelatinum gelatin; N.L. neut. adj. lyticum (from Gr. neut. adj. lutikon) able to loosen, able to dissolve; N.L. neut. adj. gelatinilyticum gelatin-dissolving, referring to the property of being able to hydrolyse gelatin].

Cells are motile, pleomorphic - showing different shapes (short rods, irregular cocci and ovals, mean cell dimensions 1-2 $\mu \mathrm{m}$ ) under optimal growth conditions - and stain Gram-negative. Colonies on agar plates containing 3.4$3.9 \mathrm{M} \mathrm{NaCl}$ are red, elevated and round. Chemoorganotrophic and aerobic. Growth occurs at $20-50{ }^{\circ} \mathrm{C}$ (optimum $37{ }^{\circ} \mathrm{C}$ ), in the presence of $1.7-5.1 \mathrm{M} \mathrm{NaCl}$ (optimum 3.4-3.9 M NaCl) and $0-1.0 \mathrm{M} \mathrm{MgCl}_{2}$ (optimum $0.1 \mathrm{M} \mathrm{MgCl}_{2}$ ), and at $\mathrm{pH}$ 5.5-9.0 (optimum $\mathrm{pH}$ 7.0). Cells lyse in distilled water and the minimal $\mathrm{NaCl}$ concentration to prevent cell lysis is $10 \%(\mathrm{w} / \mathrm{v})$. Catalase- and oxidase-positive. Does not grow under anaerobic conditions with nitrate, arginine or DMSO.
Nitrate is not reduced to nitrite. $\mathrm{H}_{2} \mathrm{~S}$ is not produced from sodium thiosulfate. Indole formation is positive. Hydrolyses gelatin and starch (the latter only weakly) but not casein or Tween 80. The following substrates are utilized as single carbon and energy sources for growth: D-glucose, D-mannose, D-galactose, sucrose, lactose, starch, glycerol, D-sorbitol, acetate, pyruvate, DL-lactate, L-alanine, L-glutamate and L-ornithine. No growth occurs on D-fructose, L-sorbose, D-ribose, D-xylose, maltose, D-mannitol, succinate, L-malate, fumarate, citrate, glycine, L-arginine, L-aspartate or L-lysine. Acid is produced from D-glucose, D-mannose, D-galactose, sucrose and lactose. Sensitive to the following antibiotics ( $\mu$ g per disc, unless otherwise indicated): novobiocin (30), bacitracin (0.04 IU per disc), anisomycin (20), aphidicolin (20) and rifampicin (5). Resistant to the following antibiotics: erythromycin (15), penicillin G (10 IU per disc), ampicillin (10), chloramphenicol (30), neomycin (30), norfloxacin (10), ciprofloxacin (5), streptomycin (10), kanamycin (30), tetracycline (30), vancomycin (30), gentamicin (10) and nalidixic acid (30). The polar lipids are PG, PGP-Me, trace PGS, and one major glycolipid and one minor glycolipid chromatographically identical to S-DGD-1 and DGD-1, respectively; three trace unidentified glycolipids may be present. The DNA $\mathrm{G}+\mathrm{C}$ content of the type strain is $64.0 \mathrm{~mol} \%$ (as determined by HPLC).

The type strain, TNN44 ${ }^{\mathrm{T}}\left(=\mathrm{CGMCC} 1.10119^{\mathrm{T}}=\mathrm{JCM}\right.$ $16426^{\mathrm{T}}$ ), was isolated from Tainan marine solar saltern near Lianyungang city, Jiangsu province, China.

\section{Description of Halogranum amylolyticum sp. nov.}

Halogranum amylolyticum [a.my.lo.ly'ti.cum. Gr. n. amylon starch; N.L. neut. adj. lyticum (from Gr. neut. adj. lutikon) able to loosen, able to dissolve; N.L. neut. adj. amylolyticum starch-dissolving, referring to the property of being able to hydrolyse starch].

Cells are non-motile, pleomorphic - showing different shapes (irregular cocci and ovals, mean cell dimensions 1-2 $\mu \mathrm{m}$ ) under optimal growth conditions - and stain Gram-negative. Colonies on agar plates containing 3.4 M $\mathrm{NaCl}$ are red, elevated and round. Chemo-organotrophic and aerobic. Growth occurs at $20-50{ }^{\circ} \mathrm{C}$ (optimum $37^{\circ} \mathrm{C}$ ), in the presence of 1.4-5.1 M NaCl (optimum $3.4 \mathrm{M} \mathrm{NaCl}$ ) and $0-1.0 \mathrm{M} \mathrm{MgCl}_{2}$ (optimum $0.05 \mathrm{M} \mathrm{MgCl}_{2}$ ), and at pH 5.5-9.0 (optimum pH 6.5). Cells lyse in distilled water and the minimal $\mathrm{NaCl}$ concentration to prevent cell lysis is $8 \%(\mathrm{w} / \mathrm{v})$. Catalase- and oxidase-positive. Does not grow under anaerobic conditions with nitrate, arginine or DMSO. Reduces nitrate to nitrite. $\mathrm{H}_{2} \mathrm{~S}$ is not produced from sodium thiosulfate. Indole formation is positive. Hydrolyses starch but not gelatin, casein or Tween 80 . The following substrates are utilized as single carbon and energy sources for growth: D-glucose, D-mannose, D-galactose, maltose, sucrose, lactose, starch, glycerol, D-mannitol, D-sorbitol, acetate, pyruvate, DL-lactate, succinate, L-malate, fumarate, glycine, L-alanine, L-glutamate and L-ornithine. 
No growth occurs on D-fructose, L-sorbose, D-ribose, D-xylose, citrate, L-arginine, L-aspartate or L-lysine. Acid is produced from D-glucose, D-mannose, D-galactose, maltose, sucrose and lactose. Sensitive to the following antibiotics ( $\mu \mathrm{g}$ per disc, unless otherwise indicated): novobiocin (30), bacitracin (0.04 IU per disc), anisomycin (20), aphidicolin (20) and rifampicin (5). Resistant to the following antibiotics: erythromycin (15), penicillin G (10 IU per disc), ampicillin (10), chloramphenicol (30), neomycin (30), norfloxacin (10), ciprofloxacin (5), streptomycin (10), kanamycin (30), tetracycline (30), vancomycin (30), gentamicin (10) and nalidixic acid (30). The polar lipids are PG, PGP-Me, trace PGS, and one major glycolipid and one minor glycolipid chromatographically identical to S-DGD-1 and DGD-1, respectively; two trace unidentified glycolipids may be present. The DNA G $+\mathrm{C}$ content of the type strain is $62.0 \mathrm{~mol} \%$ (as determined by HPLC).

The type strain, $\mathrm{TNN}^{2} 8^{\mathrm{T}}\left(=\mathrm{CGMCC} 1.10121^{\mathrm{T}}=\mathrm{JCM}\right.$ $16428^{\mathrm{T}}$ ), was isolated from Tainan marine solar saltern near Lianyungang city, Jiangsu province, China.

\section{Acknowledgements}

This work was supported by the National Natural Science Foundation of China (No. 30970006).

\section{References}

Antón, J., Oren, A., Benlloch, S., Rodríguez-Valera, F., Amann, R. \& Rosselló-Mora, R. (2002). Salinibacter ruber gen. nov., sp. nov., a novel, extremely halophilic member of the Bacteria from saltern crystallizer ponds. Int J Syst Evol Microbiol 52, 485-491.

Chun, J., Lee, J.-H., Jung, Y., Kim, M., Kim, S., Kim, B. K. \& Lim, Y.-W. (2007). EzTaxon: a web-based tool for the identification of prokaryotes based on $16 \mathrm{~S}$ ribosomal RNA gene sequences. Int J Syst Evol Microbiol 57, 2259-2261.

Cui, H.-L., Lin, Z.-Y., Dong, Y., Zhou, P.-J. \& Liu, S.-J. (2007). Halorubrum litoreum sp. nov., an extremely halophilic archaeon from a solar saltern. Int J Syst Evol Microbiol 57, 2204-2206.

Cui, H.-L., Zhou, P.-J., Oren, A. \& Liu, S.-J. (2009). Intraspecific polymorphism of $16 \mathrm{~S}$ rRNA genes in two halophilic archaeal genera, Haloarcula and Halomicrobium. Extremophiles 13, 31-37.

Cui, H.-L., Gao, X., Sun, F.-F., Dong, Y., Xu, X.-W., Zhou, Y.-G., Liu, H.-C., Oren, A. \& Zhou, P.-J. (2010). Halogranum rubrum gen. nov., sp. nov., a halophilic archaeon isolated from a marine solar saltern. Int J Syst Evol Microbiol 60, 1366-1371.
De Ley, J., Cattoir, H. \& Reynaerts, A. (1970). The quantitative measurement of DNA hybridization from renaturation rates. Eur $J$ Biochem 12, 133-142.

Dussault, H. P. (1955). An improved technique for staining red halophilic bacteria. J Bacteriol 70, 484-485.

Fitch, W. M. (1971). Toward defining the course of evolution: minimum change for a specific tree topology. Syst Zool 20, 406-416.

Gonzalez, C., Gutierrez, C. \& Ramirez, C. (1978). Halobacterium vallismortis sp. nov. An amylolytic and carbohydrate-metabolizing, extremely halophilic bacterium. Can J Microbiol 24, 710-715.

Gutiérrez, C. \& González, C. (1972). Method for simultaneous detection of proteinase and esterase activities in extremely halophilic bacteria. Appl Microbiol 24, 516-517.

Gutiérrez, M. C., Castillo, A. M., Kamekura, M. \& Ventosa, A. (2008). Haloterrigena salina sp. nov., an extremely halophilic archaeon isolated from a salt lake. Int J Syst Evol Microbiol 58, 2880-2884.

Huß, V. A. R., Festl, H. \& Schleifer, K. H. (1983). Studies on the spectrophotometric determination of DNA hybridization from renaturation rates. Syst Appl Microbiol 4, 184-192.

Kates, M. (1986). Techniques of Lipidology, 2nd rev. edn. Amsterdam: Elsevier.

McDade, J. J. \& Weaver, R. H. (1959). Rapid methods for the detection of gelatin hydrolysis. J Bacteriol 77, 60-64.

Mesbah, M., Premachandran, U. \& Whitman, W. B. (1989). Precise measurement of the $\mathrm{G}+\mathrm{C}$ content of deoxyribonucleic acid by high-performance liquid chromatography. Int J Syst Evol Bacteriol 39, 159-167.

Ng, W.-L., Yang, C.-F., Halladay, J. T., Arora, A. \& DasSarma, S. (1995). Protocol 25. Isolation of genomic and plasmid DNAs from Halobacterium halobium. In Archaea: a Laboratory Manual: Halophiles, pp. 179-180. Edited by S. DasSarma \& E. M. Fleischmann. Cold Spring Harbor, NY: Cold Spring Harbor Laboratory.

Oren, A. (2002). Halophilic Microorganisms and their Environments. Dordrecht: Kluwer.

Oren, A., Ventosa, A. \& Grant, W. D. (1997). Proposed minimal standards for description of new taxa in the order Halobacteriales. Int J Syst Bacteriol 47, 233-238.

Saitou, N. \& Nei, M. (1987). The neighbor-joining method: a new method for reconstructing phylogenetic trees. Mol Biol Evol 4, 406-425.

Stackebrandt, E. \& Goebel, B. M. (1994). Taxonomic note: a place for DNA-DNA reassociation and $16 S$ rRNA sequence analysis in the present species definition in bacteriology. Int J Syst Bacteriol 44, 846849.

Tamura, K., Dudley, J., Nei, M. \& Kumar, S. (2007). MEGA4: molecular evolutionary genetics analysis (MEGA) software version 4.0. Mol Biol Evol 24, 1596-1599.

Vaskovsky, V. E. \& Kostetsky, E. Y. (1968). Modified spray for the detection of phospholipids on thin-layer chromatograms. J Lipid Res 9, 396. 